\title{
ENERGY INTENSITY OF DEVELOPMENT AND THE PRECONDITIONS FOR ITS ABATEMENT: AN ECONOMETRIC ANALYSIS, WITH EMPHASIS ON THE CIS COUNTRIES
}

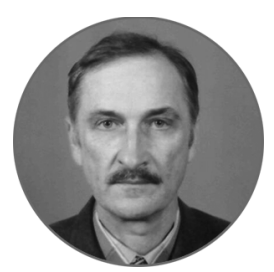

\section{Article history:}

Received 13 July 2017

Received in revised form

20 September 2017

Accepted 10 October 2017

Translated 3 November 2017

Available online 14 December 2017

JEL classification: C01, C21, C24, 043, Q43

Keywords: energy efficiency, energysaving technology, econometric analysis, fuel tariffs, quality, state institutions

\begin{abstract}
Importance The article focuses on the issues of development of the macroeconomic and institutional environment necessary to reduce energy intensity in the CIS countries.

Objectives The paper aims to develop a methodological approach based on econometric analysis of a sample of global statistical reports to justify the energy intensity abatement.

Methods I use methods of comparative analysis, linear and non-linear regressions, equations with threshold values, and the methods of index numbers.

Results The article proves that existing statistics can be used to justify factors influencing the energy intensity of the economy in the context of both demand and supply. As the comparative analysis shows, the regulatory quality is a key factor in reducing energy intensity in the CIS countries.

Conclusions and Relevance The CIS countries have the potential for improving the energy efficiency. This requires building the potential of State institutions and focusing on the development of competitive markets for energy products, energy auditing, adoption of power-saving standards, limitation of shadow economy, and more intensive counteraction to corruption.
\end{abstract}

The editor-in-charge of this article was Irina M. Vechkanova Authorized translation by Irina M. Vechkanova

\section{Introduction}

As confirmed by the World Bank data, high energy intensity or low energy efficiency in the CIS countries remain a topical issue. For instance, as seen in the selected countries of the world ${ }^{1}$, in 2000-2016,

\footnotetext{
${ }^{\dagger}$ For the source article, please refer to: Чепель С.В. Энергоемкость развития и предпосылки ее ограничения: эконометрический анализ с акцентом на страны СНГ. Финансы и кредит. 2017. Т. 23. Вып. 40. С. 2420-2436. URL: https://doi.org/10.24891/fc.23.40.2420

${ }^{1}$ The analysis is based on the sample of 50 developing countries (eight CIS countries among them) that have identical parameters as the leading CIS countries. Selection criteria are as follows: GDP per capita within USD 3-25 thousand by PPP; population of at least five million people; manufacturing sector accounting for at least 20 percent of GDP. It ensured the comparability of the sampled and CIS countries
}

the energy efficiency index (GDP per unit of primary energy consumed, i.e. the inverse indicator of energy intensity ${ }^{2}$ ) ranged between USD 8-10, demonstrating

\footnotetext{
and relative homogeneity of international statistics used for purposes of the analysis.

${ }^{2}$ I present energy efficiency in this simplified form (as the inverse value of energy intensity: Energy Efficiency = 1 / Energy Intensity) due to the specifics of the subject of research (entire economy) and unavailability of other preciser indicators for the 50 sampled developing countries involved into the econometric and comparative analysis. The existing approaches to measuring energy efficiency require identifying industrial and sectoral indicators of energy efficiency (I. Bashmakov et al. [1], M. Boiko [2]), attention to environmental and social consequences for the share of renewable energy sources and dependence on external factors (V. Tsibilina [3]), construction of relevant integral indices.
} 
a sustainable growth, though this indicator was significantly lower, i.e. USD 5 as shown in Fig. 1, in the leading CIS countries (Russia, Ukraine, Kazakhstan, Uzbekistan). Furthermore, while Uzbekistan and Ukraine managed to narrow the gap, albeit insubstantially, it widened in Kazakhstan.

It means that low energy efficiency lies deep in economies in transit as compared with other emerging economies since the former USSR and dominated States were developing under the command and administration system for many decades. The command and administration system is known to imply the wasteful use of resources for growth.

There was a prevalence of State-financed enterprises in those countries, which had no incentives for growth and implementation of new resource-saving technologies, efficiency energy policy institutions and any competition among them. Therefore, CIS countries should prioritize resource- and energysaving policies for tackling the issue. It is evidenced with respective program documents on energy saving those countries adopt and implement ${ }^{3}$.

\section{Why is Energy Intensity Abatement Important?}

High energy and resource consumption implies resources, materials, energy supplies prevail in the amount of costs for production of finished goods. It undermines the competitiveness and marketability of the finished goods in the external market. Energy- and resource-rich countries usually have excessive demand for natural capital, thus causing its quick depletion and subsequent negative effects on development sustainability [1-4].

As for other distinctions, such economies often significantly depend on external factors and have high unemployment and poverty rates, underdeveloped small business, with their economic growth longing for considerable financial injections. The economies concurrently face a shortage of energy and resources, ineffective structure

\footnotetext{
${ }^{3}$ I refer to the State Program, Energy Saving and Enhancement of Energy Efficiency up to 2020, in Russia and Presidential Directive, The Program of Measures for Reducing Energy Intensity, Implementing Energy Saving Technologies in Commercial and Social Sectors for 2015 2019 of May 5, 2015 № ПП-2343, etc.
}

dominated by industries that intensively consume interim products per unit of value added ${ }^{4}$.

If the energy saving strategy is adopted, it will give a strong impetus to the innovative economy development (K. Ermolaev [5]) because an innovative activity boost in power engineering is an important driver for modernizing national economies.

Energy efficiency is one of the crucial components of the potential inflation level (S. Chepel' [6]). That is, the higher energy efficiency, the lower the inflation rate, thus providing more opportunities for economic growth funding at minimum inflation risks.

Unless factors and conditions for the energy intensity abatement are not comprehended at the macroeconomic level, it is difficult to make long-term forecasts of GDP (V.A. Volkonskii et al. [7], A.I. Kuzovkin [8]), assess risks and formulate a long-term development strategy (K. Kaygusuz [9]). In this respect, it is reasonable to conduct a factor analysis of conditions, premises and sources of energy efficiency growth at the macroeconomic level, laying the basis for this article.

\section{Existing Possibilities for Energy Intensity Abatement: A Cross-Country Comparison}

Comparing energy efficiency and its changes throughout a 15 year time in the sample of developing countries worldwide (Fig. 2), it is noticeable that developing countries, with the CIS among them, have a substantial opportunity for an energy efficiency breakthrough.

This conclusion stems from the fact that Top-10 countries with the highest growth in energy efficiency include four economies in transit (Azerbaijan, Romania, Tajikistan and Belarus).

At this point, a logic question arises. Why have some countries managed to increase their energy efficiency by USD 5.4 and more, while the others still have same or worse indicators (Thailand, Guatemala, Egypt, etc.)? What macroeconomic, institutional, financial and other solutions are needed? Do they exist in Russia and other CIS countries?

\footnotetext{
${ }^{4}$ The respective analysis of Russia's economy is performed in proceedings by I. Bashmakov [1, 4], N. Gukasova [5] and some others.
} 
Having analyzed existing researches on this issue worldwide, I found out the majority of them focus on industry-specific and technological aspects, overlooking macroeconomic and institutional conditions, especially for emerging economies and CIS countries.

Viewing the issue systemically, factors are entirely divided into two streams, i.e. factors driving energy efficiency trends in terms of demand and supply. For example, Cambridge Econometrics report ${ }^{5}$ attributes prices for energy resources, governmental policy for energy efficiency promotion (inter alia anti-trust policy and development of competitive markets) and consumer preferences to factors influencing demand (incentives for energy efficiency growth).

Factors influencing supply include the production of energy efficient equipment, R\&D (innovative impact of technologies, including renewable energy sources), energy efficient utilities and power supply, energy conserving buildings and cost-effective transport.

The research justifies the assumption that energy efficiency investment is more lucrative than investment in new generating capacities. Furthermore, it is worth mentioning those manufacturing industries, which manufacture energy conserving equipment and materials and create more jobs per investment unit than throughout the economy on average.

Other proceedings state energy efficiency impediments shall be overcome to identify its factors and conditions. Most of such researches qualify the following factors as the main barriers hindering energy efficiency, i.e. no access to capital and investment resources, no incentives for energy conservation (low prices for energy resources, low competition in the domestic market), regulatory and administrative obstacles (nonexistent standards, laws, mechanisms for energy accounting (A.K. Reddy [10] J. Sutherland [11])), technological barriers (unavailability of energy efficient equipment, focus on efficiency of certain components instead of overall energy efficiency, lack of technical personnel

\footnotetext{
${ }^{5}$ Assessing the Employment and Social Impact of Energy Efficiency. Final Report. Volume 1: Main Report. Cambridge, Cambridge Econometrics, 2015, 139 p.
}

(W.H. Golove et al. [12]), institutional barriers (weak contractual institutions, nonexistent policy on energy, etc.), market failures (shortage or dearth of information, information asymmetry, etc.), lack of knowledge and qualification (N. Eyre [13], UNDP', S. Sorrell ${ }^{7}$ ).

Some studies focus on correlations between energy efficiency and institutional environment (regulatory quality) through an empirical econometric analysis. For instance, in his research N.I. Suslov [14] evaluated how the regulatory quality influenced energy efficiency, figuring out that the Russian economy demonstrated low energy efficiency due to frail incentives for energy conservation and drawbacks of the existing institutional mechanism.

Robust governmental institutions are the cornerstone for creating incentives (motivation) for energy saving. They may include factors of competition and tariffs. The ratio of gas/electricity/heat tariffs plays an important role in energy conservation. In many developing countries, power rates do not reflect their real value, being lower than their marginal cost for power generation. In the context, subsidies shall also be pointed out (no cost-based tariffs). As a result, subsidies for energy make energy efficiency measures less lucrative (A.K. Reddy [10], J. Sutherland [11], W.H. Golove et al. [12], S. Meyers [15], D. Farrell et al. [16]).

\section{Are These Hypotheses and Assumptions Immanent in CIS Countries and Other Developing Countries?}

Answering the above question, I performed a cross-country econometric analysis by making a sample of 50 developing countries. Analyzable factors were selected in accordance with theoretical views and information resources of international organizations (first of all, World Bank indicators).

Finally, the analyzable factors comprise 16 indicators describing the initial development level of

\footnotetext{
${ }^{6}$ World Energy Assessment: Energy and the Challenge of Sustainability. New York, United Nations Development Programme, $2000,508 \mathrm{p}$.

${ }^{7}$ Sorrell S., Schleich J., Scott S. et al. Barriers to Energy Efficiency in Public and Private Organizations: Final Report to the European Commission. Project JOS3CT970022, Environment and Energy Programme, September 2000, 9 p.
} 
an economy and its structure (manufacturing industries as percentage of GDP), liberalization and openness (for evaluating the development of competitive markets), investing activity, contributions to human capital and new technologies (investment, expenses for education, R\&D as percentage of GDP), parameters of energy tariff policies (diesel price per liter in USD), regulatory quality (Control of Corruption Index, Rule of Law index, Government Effectiveness, ranging from 1 to 5) and labor potential (percentage of qualified manpower out of total employed). Moreover, the analysis involved a conditional variable for well-resourced countries ( 1 for well-resourced countries, such as Russia, Kazakhstan, Uzbekistan, etc. and 0 for the others), and the annual mean temperature in degrees centigrade. For comparability of time, all value-based indicators were used as constant prices as of 2000.

When choosing analysis methods, I consider structural distinctions of matrices in line with the analyzable indicator. First of all, the structure consists of, to various extents, reporting statistics of separate lines and columns of initial matrices (indicators) on certain countries in the sample. It can be illustrated with missing trend data on such indicators as expenses for education, science and technologies, employed population with higher education, prices for energy supplies and some others.

It substantially hinders the use of classical methods for panel analysis (RE, FE, etc.). The cross-section analysis method turns out to be the only alternative in this case with respect to the fifty developing countries in the sample.

However, the question arises concerning the form such indicators are used in the analysis, i.e. their values as of the last year of the reporting period (the 2013 level), average annual values for the entire reporting period, changes in the indicator for the reporting period (the 2013 value less the 2000 value).

As proved through the correlation analysis of the resulting statistical basis, the third form of variables (their changes) prevails. If variables are used as their 2013 level, energy efficiency and its factors reveal only two statistically significant coefficients of correlation with logically consistent signs (economic freedom with the coefficient of +0.4002 and control of corruption of $+0.2689 *)$, a choice of average annual values results in four factors, while a choice of changes in indicators for the period leads to seven factors (initial development level, investment factors, prices for energy carriers, regulatory became significant).

The econometric analysis involves a number of steps. At the first step, I search for traditional linear regressions with as many statistically significant factors as possible that would meet theoretically consistent signs of their coefficients relating to a certain factor (model L). At the second step when the results are used, I test nonlinear dependence of those factors to be included into equations as per the existing theory but appeared statistically insignificant (model NL). At the final step, I evaluate regressions with thresholds for the regulatory quality (Model TH). The respective results are presented in Table 1 and hereinafter.

As the analysis reveals, investment ${ }^{8}$ and diesel tariffs prove, in the absolute majority of combinations, to be the most sustainable and statistically significant ${ }^{9}$ among traditional linear multivariate regressions for this sample of countries. For the analyzable group of countries the first factor verifies the assumption that investing activity should be boosted for raising energy efficiency (factor of supply). Increased investing activity is believed to arise inter alia from replacement of obsolete, energy-consuming equipment, production of energy-saving devices and machines, and release of cost-effective cars, retrofitting of thermal power grids and construction of energy efficient buildings and facilities, improved structure of an economy, rapid growth in new industries and services with moderate energy demand.

The second factor ${ }^{10}$ generates demand for energysaving technologies and fuel-efficient vehicles. As

\footnotetext{
${ }^{8}$ The result of the investment factor is tentative and subject to further specification, since a growth in investment can influence not only energy efficiency, but also GDP (the relevance of endogeneity studies).

${ }^{9}$ The factors marked with asterisks:

*** - 1-percent significance, ** - 5-percent significance, * - 10-percent significance.
} 
the result shows, effective tariff regulation, development of commodity markets, conditions for industrial small business, other mentioned premises constitute one of the principal requirements for abating the energy intensity of an economy as a whole in the majority of emerging countries and CIS countries.

Government effectiveness and initial level of annual mean temperature proved to be other factors that demonstrated their statistical significance if included into a linear regression (Models L1-L3). Being combined with the first two factors, they explained from 33 to 44 percent of fluctuations in energy efficiency trends within the analyzable group of countries.

Whereas the government effectiveness factor is statistically significant, it proves the importance of increasing the quality of public services, i.e. the efficiency of public administration, efficacy of reforms, securing guarantees for property rights and other contemporary requirements to the State. Thisfactor turns to be especially influential on resource-rich developing countries (conditional variable inresr), including inter alia some CIS countries (Russia, Kazakhstan, Uzbekistan). This is evident from the fact that the coefficient of the goveff factor significantly rises (from +2.75 up to +5.68) when model L2 is substituted with model L3, where the factor is integrated into the regression as the product of goveff*inresr. The possible reason is that the effective government ensures more reasonable use of revenue from export of natural resources by setting pools of development funds, adhering to fiscal rules and other mechanisms for reinforcing technological, S\&T and human capital. It also exerts more stringent control over the reasonable use of energy resources and reduce their loss.

As for a positive correlation between energy efficiency and average mean temperature in the country, it could be possibly explained by the prevalence of obsolete and worn-out systems of heat and hot water supply in cities of the CIS

\footnotetext{
${ }^{10}$ I have chosen the diesel tariff indicators in line with available information in the World Bank database since there are not other indicators reflecting prices for secondary energy resources (prices for petrol, electricity, etc.).
}

countries with cold climate. Such systems require ongoing technical maintenance and cause substantial energy losses ${ }^{11}$ [17]. In the mean time, energy efficiency elasticity is low for this factor (from +0.053 to +0.083 ). It may reflect other correlations with the opposite sign. For example, higher electricity consumption in hot countries due to air conditioning and irrigation.

As for other possible areas and conditions for energy efficiency growth (increased openness of economy, improvement of the economy structure, increased expenses for education, R\&D, etc.), expected results were not attained with respective indicators introduced into linear regression factors (statistical insignificance of respective coefficients or illogical signs. Refer to model L3 with the manufacturing sector becoming a new factor). Hence, I test the hypothesis on the nonlinear correlation between those factors and energy efficiency.

The hypothesis was verified concerning two factors, i.e. the share of manufacturing industries as of the beginning of the period and the degree of economy openness (as of the beginning of the period, please refer to models L4, L5). They were included into the regression as a second degree polynomial. This form implies an inflection point and changes in the factor effect on energy efficiency provided that the factor takes on a certain value. Relying upon calculations for the initial development level of manufacturing industries inmanuf, I conclude that the industry expansion (percentage of GDP), in the given sample of emerging economies, has an adverse effect on energy intensity initially. The industry expansion has a positive effect if only the industry accounts for 35 to 40 percent of GDP.

This may be due to the fact that traditional types of production prevail in the industry structure at the initial development phase (fabrics, food, construction materials, conventional chemical products, etc.). They have relatively high energy intensity of output. When the industry reaches a certain technological level, modern manufacturing types take a lead (electronics, components). They

\footnotetext{
${ }^{11}$ This conclusion is consistent with findings made in the research by R.R. Khabibrakhmanov and others, stating that energy intensity of economy has a negative correlation with annual mean temperature.
} 
have high value added and relatively low specific energy intensity.

At the final step of the analysis, I examine whether the hypothesis of threshold values in regulatory quality indicators is applicable to the sample. Threshold overrun provides for a positive and statistically significant effect of the remaining factors, which are not included into models L1-NL2 (Table 1). For this purposes, I use a linear regression with the following threshold values:

$$
\begin{aligned}
& \text { eneff }=c+a_{1} \cdot C V_{1}+a_{2} \cdot C V_{2} \ldots+\beta_{1} \cdot\left(t h_{1}-Q I\right) \cdot R 1+ \\
& +b_{2} \cdot\left(t h_{2}-Q I\right) \cdot R_{2}+\ldots(\text { Model } T H),
\end{aligned}
$$

where eneff is energy efficiency;

$Q /$ is regulatory quality (Control of Corruption Index corrup, Government Effectiveness goveff, etc.);

$R_{1,2 \ldots n}$ stands for potential drivers of energy efficiency growth, with their effect on energy intensity of an economy depending on the regulatory quality (increased expenses for education, growing fuel tariffs, greater extent of economic openness, etc.);

$C V_{1,2 \ldots n}$ stands for control variables, such as investment, conditional variable for countries with large natural resource endowments, input conditions, etc.;

$c$ is a constant;

$a_{1,2 \ldots n}, b_{1,2 \ldots n}$ are regression coefficients.

If the regression estimation reveals negative results and significance of the coefficient $b$, as well as a positive and significant value of the parameter th, the $R$-factor growth will invoke an increase in energy efficiency only in case the regulatory quality QI of a certain country exceeds the threshold value th.

Having tested this correlation form, I obtain two models for such factors as education expenses and $S \& T$ costs. The first one is expressed as follows:

$$
\begin{aligned}
& \text { Eneff }=-1,56+0,067 \cdot \text { intemp }+0,188 * \text { invest }+ \\
& +5,11 \cdot \text { goveff } \cdot \text { inresr }+2,8 \cdot \text { diesel }+
\end{aligned}
$$

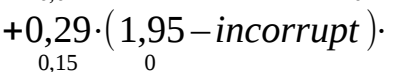

$$
\begin{aligned}
& \text {-edbudlagv (Model TH1) } \\
& R 2=0,42 \quad S E=1,97 \quad \text { num. of obs. }=43
\end{aligned}
$$

In this case, the education expenses factor is used as education expenses as percentage of total budgetary spending with a certain lag (ranging from three to five years). It verifies the hypothesis stating that increased education expenses influence energy efficiency in a certain period of time, rather than immediately.

The model's coefficients are of statistical significance as proved with the pval value indicated in brackets under the coefficients. The coefficient of the edbudlagv factor (-0.29) is the only exception, but its pval value of 0.15 approximates the 10-percent level of significance.

The threshold value of the Corruption of Control Index (initial value, incorrup) is 1.95 implying that increased education expenses will have a positive effect on energy efficiency provided that the index is above 1.95 . The more the index in a certain country exceeds this value, the greater effect increased expenses have on energy efficiency.

The result can be interpreted as follows. The low Control of Corruption Index signifies the possibility of deriving big income that has no relation to labor productivity or qualification. It suppresses motivation for good education, making it formalistic and affecting the quality of teaching. This situation causes an outflow of the most promising and creative students and streams them to foreign universities. It reduces the share of qualified talent needed to address energy saving issues. In such circumstances, increased education expenses will not substantially solve the problem of energy efficiency.

In the majority of the sampled countries, this index exceeds its threshold value. The average and median values were 2.09 and 2.01 respectively. It means increased education expenses are one of the factors improving energy efficiency in those countries.

In the mean time, regulatory quality in relation to the edbud factor is not enough for the leading CIS countries to solve the problem of energy efficiency. As of the beginning of the reporting period, this index was 1.6 in Russia and Uzbekistan, while it was 1.42 in Kazakhstan and Ukraine, being significantly lower than the required threshold value (1.95). 
S\&T expenses became the second factor. The resultant model is expressed as follows:

$$
\begin{aligned}
& \text { Eneff }=-1,81+0,07 \cdot \text { intemp }+0,17 \cdot \text { invest }+ \\
& +7,11 \cdot \text { goveff } \cdot \text { inresr }+2,94 \cdot \text { diesel }- \\
& \text {-3,61·(3,01-incorrup)·rnd01 (Model TH 2) } \\
& R 2=0,47 \quad S E=1,76 \text { num. of obs } .=42
\end{aligned}
$$

Six countries in the sample meet the criterion. These are South Africa (3.1), Poland (3.05), Hungary (3.2), Costa Rica (3.26), Chile (4.04), Botswana (3.17). Hence, in the absolute majority of emerging countries, increased S\&T expenses will not approximate the resource-saving model of development, unless regulatory quality and potential grow exponentially, thus ensuring positive and sustainable trends in the Control of Corruption Index and regulatory quality.

I obtain the similar result from the sample of average annual estimates of the indicators concerning the diesel tariff factor. The respective regression equation is expressed as follows:

$$
\begin{aligned}
& \text { Eneff }=8,77+0,08 \cdot \text { temp -1,54 } \cdot \text { inresr - }
\end{aligned}
$$

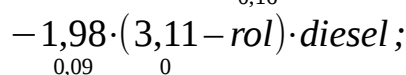

$$
\begin{aligned}
& R 2=0,13 \quad S E=3,2 \quad \text { num. of obs } .=49 \text {. } \\
& \text { (Model TH 3) }
\end{aligned}
$$

Although the first two factors (temperature and resource endowments of a country) are formally incompliant with statistical significance criteria, coefficients for threshold estimation meet them.

The outcome means that diesel tariffs will grow without improving energy efficiency of an economy as a whole unless regulatory quality (by regulatory compliance indicator $\mathrm{rol}$ ) does not match the threshold of 3.11, being seen in Malaysia (3), Costa Rica (3), etc.

\section{What Message Do the Results Convey for Economic Policy?}

Boosting investing activities shall become a cornerstone for raising energy efficiency nationwide. It is proved with the persistence of the investment factor and its presence in all the models obtained from the econometric analysis.
Uzbekistan and other CIS countries, especially ones with sufficient resource endowments (Kazakhstan, Russia, Azerbaijan), really need to undertake relevant measures so as to improve the investment environment, grant tax and other benefits to actively investing enterprises, increase monetization levels by making lending resources more accessible and affordable. While the average annual estimate of gross investment in Uzbekistan was 22 percent of GDP in the reporting period, it exceeded 30 percent for some developing countries in the analyzable sample, i.e. China (42 percent), Iraq (37 percent), India (34 percent), Botswana (33 percent), Morocco (32 percent), etc.

Energy saving priorities of an investment policy should not be neglected. The investment policy should pursue retrofitting the most energy intensive production, adopting new energy- and resource-saving standards in construction, utilities, transport, creating modern enterprises and industries manufacturing new household devices, more energy efficient industrial and technical equipment.

Uzbekistan may benefit from retrofitting and refurbishment of electric power engineering, chemical industry, production of industrial construction materials. According to the existing estimates $^{12}$, the wear and tear level of principal generating capacities (thermal power station) accounts for 62 percent, with the average energy conversion efficiency being just 33.5 percent, that is 1.5 times as low as the identical indicator of modern thermal power stations in Southeast Asia. If six major power plants have combined cycle gas turbine units installed to generate electricity, they will cut their gas consumption down to 270-300 tonne of gas equivalent per 1 kilowatt hour of electricity as compared with the current consumption of 375 tonnes of gas equivalent. The measure will substantially save fuel and gas, in particular.

Similar reserves are made to produce fertilizers and industrial construction materials. If the Haldor Topsoe installation is used, $900 \mathrm{~m}^{3}$, instead of 1,870 $\mathrm{m}^{3}$, will be used to produce one tonne of

\footnotetext{
${ }^{12}$ Based on the Report, Energy Efficient Model of Growth, by the Center of Economic Research.
} 
ammonium. Thus, there will be a 1.5 to 2-fold reduction in operating and maintenance costs of the equipment.

Instead of the wet process, the dry process for manufacturing of cement cuts the specific consumption of gas from $230-250 \mathrm{~kg}$ of coal equivalent to $100-120 \mathrm{~kg}$ (as seen in cement manufacturing plants of Japan, Korea, China, Turkey).

A reasonable increase in tariffs for motor and other fuel is the second significant factor of energy efficiency, as the econometric analysis reveals. Average annual prices for diesel and petrol in Uzbekistan were significantly lower than the average in the sample of developing countries.

Furthermore, rapidly growing prices and tariffs for energy supplies may have a detrimental effect due to insufficiently developed institutions (please refer to Model TH3). The analysis validates this conclusions macroeconomically ${ }^{13}$. The consumption of energy resources accounts for 64 percent of the selling price of goods, say, at chemical enterprises of Uzbekistan (against 25-30 percent of identical foreign enterprises). In such circumstances, rapid growth in gas and electricity prices will instigate a commensurable rise in selling prices of fertilizers and other chemical products, undermine their competitiveness and affect enterprises' financial position, unless production facilities are fundamentally retrofitted and the quality of governance and State aid is enhanced (Fig. 3).

Raising education and R\&D expenses constitutes another tool of an economic policy to improve

\footnotetext{
${ }^{13}$ Report on energy efficient model of Uzbekistan's growth by the Center for Economic Research.
}

energy efficiency of the national economy. However, this approach and its efficacy strongly depends on the regulatory quality that should be supported with the high Control of Corruption Index. This approach is not productive in Uzbekistan since the Control of Corruption Index has been ranging from 1.2 to 1.4 for recent years, according to the World Bank data, meanwhile it shall be 1.9 for education (Model TH1) and 3 for R\&D (Model TH2). The average Control of Corruption Index is slightly higher than 2 in the given sample, being quite sufficient for increased education expenses, but inadequate for increased R\&D expenses.

Therefore, an elaborate methodological approach to the problem of high energy intensity of economy spotlights promising areas and measures for solving the issue and underpin them. The comparison of factual values of the resultant factors and conditions of Uzbekistan with threshold values and global benchmarks shows that the regulatory quality shall be improved ${ }^{14}$ as the first remedy in this case. Hence, the regulatory reform should be the top priority in the energy efficiency race. The regulatory reform is indented to expand the potential of governmental institutions in combatting corruption ${ }^{15}$ (primarily, distribution and control of energy resources), ensuring fair competition, developing competitive markets, creating the favorable investment climate and energy saving incentives, protecting investors' rights, coordinating activities of the public and private sectors for addressing this issue.

A similar analysis can be conducted for other CIS countries.

\footnotetext{
${ }^{14}$ This is a general definition used by the World Bank and other international organizations, which quantify the regulatory quality. The principal indices include Corruption Perceptions Index (CPI) (the ability of the State to design and implement anti-corruption measures); Rule of Law (RoL), Government Effectiveness (GE). You may refer to articles by I.A. Nikolaeva and E.Sh. Gontmakher concerning these and other indices of regulatory quality.

${ }^{15}$ In early 2017, the Republic of Uzbekistan adopted the Law On Combatting Corruption so as to enhance the efficacy of anti-corruption measures.
} 


\section{Table 1}

The results of econometric analysis of macroeconomic conditions and preconditions for growth of the energy efficiency of economy, in general

\begin{tabular}{|c|c|c|c|c|c|}
\hline \multirow{2}{*}{ Factors and conditions } & \multicolumn{5}{|c|}{ Dependent variable - increase in energy efficiency (eneff) } \\
\hline & Model L1 & Model L2 & Model L3 & Model NL1 & Model NL2 \\
\hline 1. Investment (invest) & $0.14^{* *}$ & 0.14 & $0.13^{* *}$ & $0.13^{* *}$ & $0.12^{*}$ \\
\hline 2. Government effectiveness (goveff) & $2.75^{* *}$ & - & - & - & - \\
\hline 3. Diesel tariffs (diesel) & $2^{*}$ & $2.49^{* * *}$ & $2.69^{* *}$ & $2.56^{* * *}$ & $2.57^{* * *}$ \\
\hline 4. Temperature level (intemp) & 0.053 & $0.069^{*}$ & $0.083^{* *}$ & $0.077^{* *}$ & $0.066^{*}$ \\
\hline $\begin{array}{l}\text { 5. Conditional variable for resource-rich countries and government } \\
\text { effectiveness (inresr*goveff) }\end{array}$ & - & $5.68^{* * *}$ & $6.01^{* * *}$ & $5.86^{* * *}$ & $4.7^{* *}$ \\
\hline 6. Share of manufacturing sector (manuf) & - & - & -0.11 & - & - \\
\hline 7. Initial share of manufacturing sector (inmanuf) & - & - & - & -0.286 & $-0.608^{*}$ \\
\hline 8. (inmanuf)2 & - & - & - & +0.0074 & $0.016^{* * *}$ \\
\hline 9. Initial openness of economy (inecopen) & - & - & - & - & $5.98^{*}$ \\
\hline 10. (inecopen)2 & - & - & - & - & $-4.34^{* *}$ \\
\hline R2 & 0.33 & 0.38 & 0.41 & 0.41 & 0.49 \\
\hline Number of countries & 48 & 48 & 47 & 47 & 44 \\
\hline SE Regression & 1.97 & 1.91 & 1.9 & 1.92 & 1.81 \\
\hline
\end{tabular}

Source:Authoring, based on the World Bank statistics for 50 developing countries comparable with Uzbekistan 


\section{Figure 1}

Dynamics of energy efficiency (EE) of the CIS in 2000-2013 in comparison with the average rates for developing countries (GDP at PPP in USD in constant prices, 2011, per $1 \mathrm{~kg}$ of oil equivalent of natural energy)

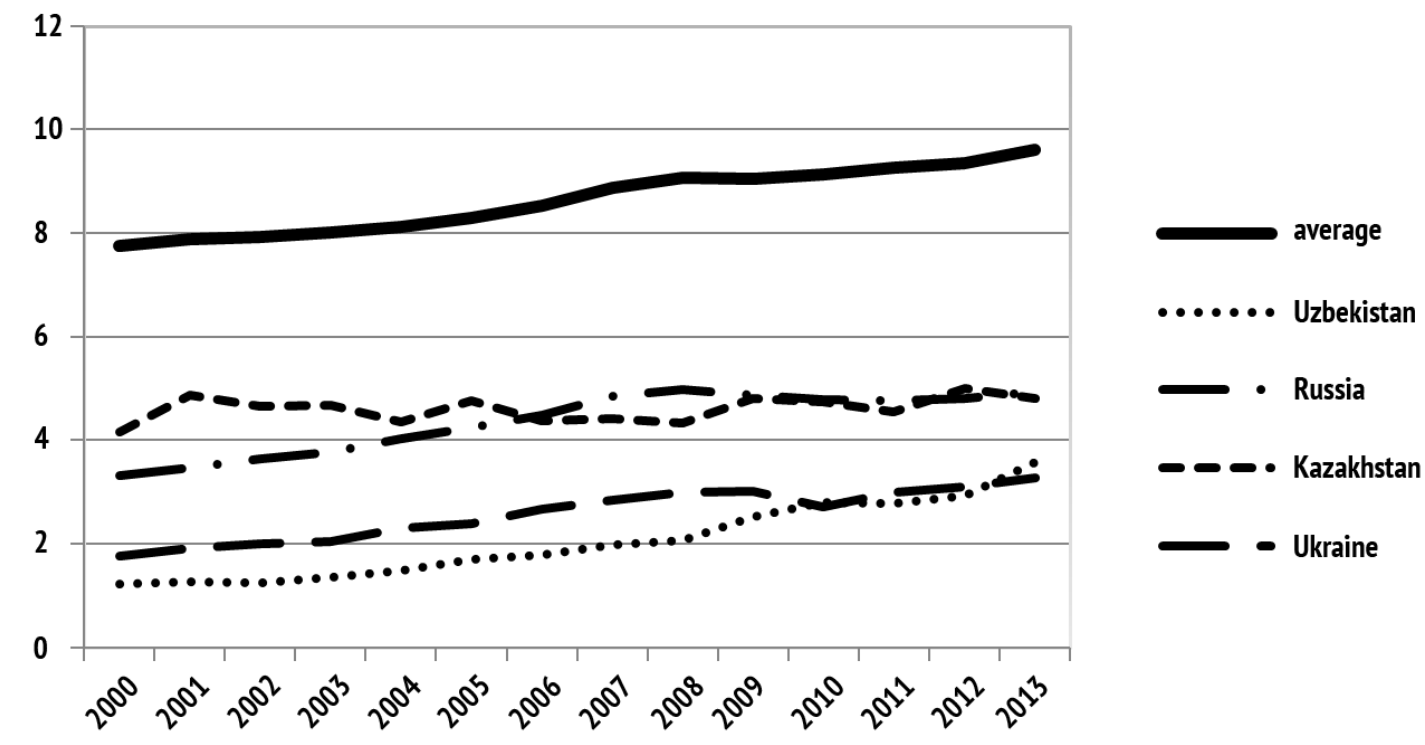

Source: Authoring, based on the World Bank WDI

\section{Figure 2}

The first and last tens of developing countries according to the criterion of energy efficiency increase in 2000-2013

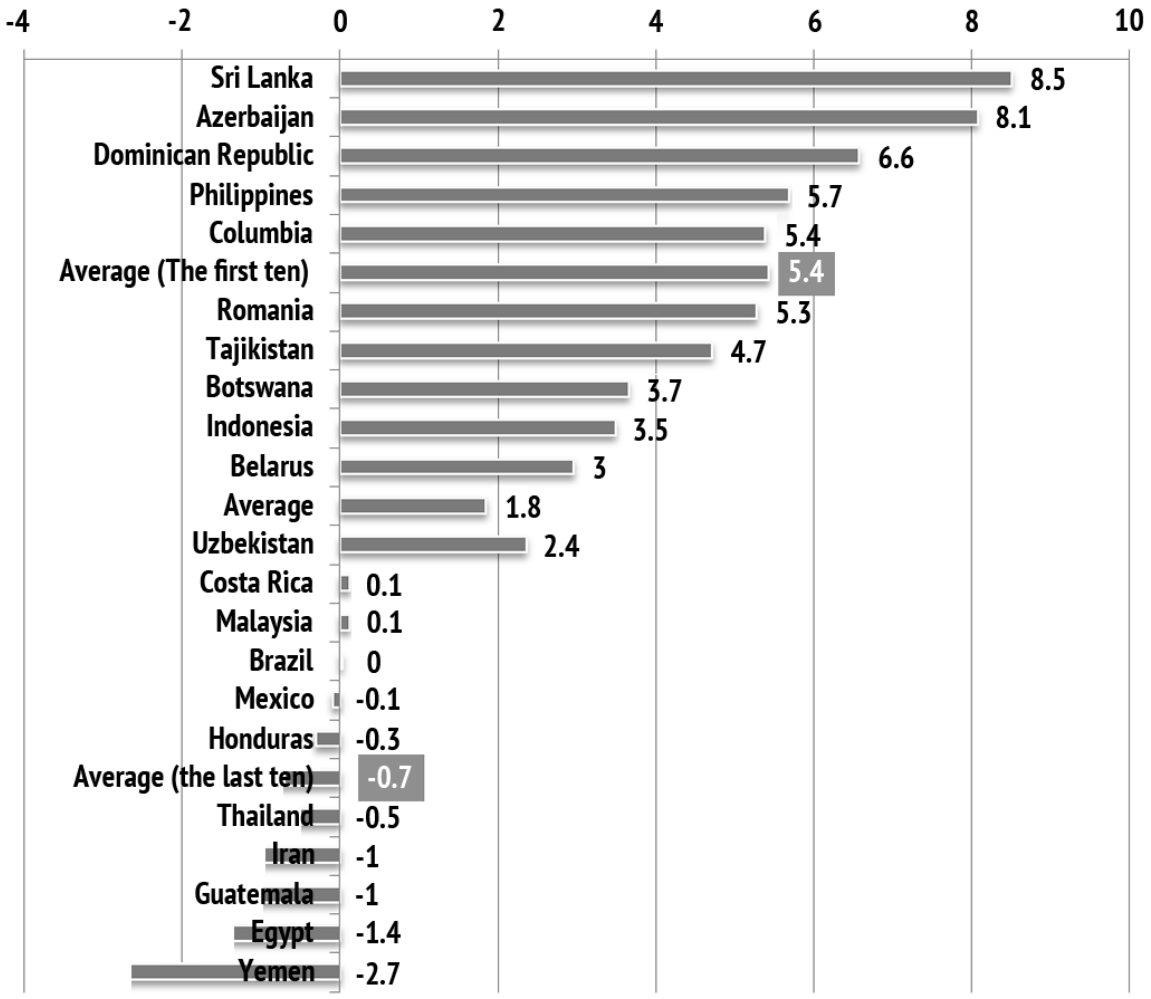

Source: Authoring, based on the World Bank WDI

Please cite this article as: Chepel' S.V. Energy Intensity of Development and the Preconditions for Its Abatement:

An Econometric Analysis, with Emphasis on CIS Countries. Digest Finance, 2017, vol. 22, iss. 4, pp. 456-467. https://doi.org/10.24891/df.22.4.456 


\section{Figure 3}

The gap between Uzbekistan (mid-year estimates for the reporting period) and the average level (average for sample of 50 developing countries) by economic policy indicator

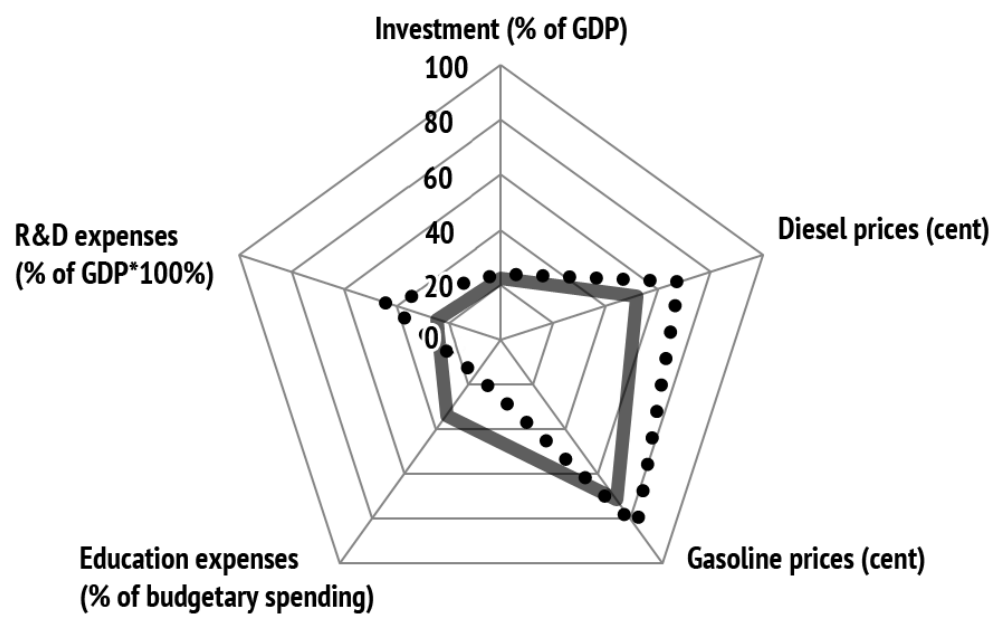

$\bullet \bullet \bullet$ Worldwide average

Uzbekistan's average

Source: The World Bank data

\section{Acknowledgments}

I express my gratitude to experts of the Korean Development Institute for valuable comments on the findings, and Sergei A. Shelest, a junior researcher at the Institute for Forecasting and Macroeconomic Research, for their assistance in preparing and systematizing global statistics used for this article.

\section{References}

1. Bashmakov I.A., Myshak A.D. [Factor Analysis of Evolution of Russian Energy Efficiency: Methodology and Outcomes]. Voprosy Ekonomiki, 2012, no. 10, pp. 117-131. (In Russ.)

2. Boiko M.S. [Energy saving as a key factor of Russian economic and national safety]. Upravlenie ekonomicheskimi sistemami, 2017, no. 2. (In Russ.)

URL: http://uecs.ru/demografiya/item/4289-2017-02-15-06-52-40?pop=1\&tmpl=component\&print=1

3. Bashmakov I.A. [What reduces the energy intensity of Russia's GDP]. Energosberezheniye, 2014, no. 1, pp. 12-17. URL: https://www.abok.ru/for_spec/articles.php?nid=5718 (In Russ.)

4. Gukasova N.R. [Instruments to increase an energy efficiency of the Russian industry]. Statistika $i$ ekonomika = Statistics and Economics, 2015, no. 1, pp. 144-148.

URL: https://cyberleninka.ru/article/n/instrumenty-povysheniya-energoeffektivnosti-rossiyskoypromyshlennosti (In Russ.)

5. Ermolaev K.A. [The impact of energy saving and energy efficiency enhancement on national economies' innovative development]. Ekonomicheskii analiz: teoriya i praktika = Economic Analysis: Theory and Practice, 2017, vol. 16, iss. 1, pp. 82-92. (In Russ.) URL: https://doi.org/10.24891/ea.16.1.82

6. Chepel' S. [How to raise the efficiency of economic policy: The empirical analysis of State institutions]. Voprosy Ekonomiki, 2009, no. 7, pp. 62-74. (In Russ.) 
7. Volkonskii V.A., Kuzovkin A.I. [Analysis and assumptions of energy consumption and energy saving of Russian economy]. Problemy prognozirovaniya = Problems of Forecasting, 2006, no. 1, pp. 53-61. URL: https://ecfor.ru/publication/analiz-i-prognoz-energoemkosti-i-energoeffektivnosti/ (In Russ.)

8. Kuzovkin A.I. [Forecast of energy consumption of GDP of Russia and developed countries as at 2020]. Problemy prognozirovaniya $=$ Problems of Forecasting, 2010, no. 3, pp. 144-148.

URL: https://ecfor.ru/publication/prognoz-energoemkosti-vvp-rossii-i-razvityh-stran-na-2020-g/ (In Russ.)

9. Kaygusuz K. Energy for Sustainable Development: A Case of Developing Countries. Renewable and Sustainable Energy Reviews, 2012, vol. 16, iss. 2, pp. 1116-1126.

URL: https://doi.org/10.1016/j.rser.2011.11.013

10. Reddy A.K.N. Barriers to Improvements in Energy Efficiency. Energy Policy, 1991, vol. 19, iss. 10, pp. 953-961. URL: http://dx.doi.org/10.1016/0301-4215(91)90115-5

11. Sutherland R.J. Market Barriers to Energy-Efficiency Investments. The Energy Journal, 1991, vol. 12, no. 3 , pp. 15-34. URL: https://doi.org/10.5547/ISSN0195-6574-EJ-Vol12-No3-3

12. Golove W.H., Eto J.H. Market Barriers to Energy Efficiency: A Critical Reappraisal of the Rationale for Public Policies to Promote Energy Efficiency. Berkeley, Energy \& Environment Division, Lawrence Berkeley National Laboratory, University of California, 1996, 66 p.

13. Eyre N. Barriers to Energy Efficiency: More Than Just Market Failure. Energy \& Environment, 1997, vol. 8, iss. 1 , pp. $25-43$.

14. Suslov N.I. Energy Saving Incentives and Institutional Environment: A Cross Country Analysis. Part 1. Mir ekonomiki i upravleniya = World of Economics and Management, 2014, vol. 14, iss. 2, pp. 61-70.

URL: https://cyberleninka.ru/article/n/energy-saving-incentives-and-institutional-environment-a-crosscountry-analysis-part-1

15. Meyers S. Improving Energy Efficiency: Strategies for Supporting Sustained Market Evolution in Developing and Transitioning Countries. Berkeley, Lawrence Berkeley National Laboratory, 1998, 79 p.

16. Farrell D., Remes J.K. How the World Should Invest in Energy Efficiency. The McKinsey Quarterly, July 2008.

17. Khabibrakhmanov R.R., Ryzhkova L.V. [Factors determining the energy consumption of the domestic economy]. Upravlenie ekonomicheskimi sistemami: elektronnyi nauchnyi zhurnal, 2012, no. 12. (In Russ.) URL: http://uecs.ru/marketing/item/1802-2012-12-14-08-08-27?pop=1\&tmpl=component\&print=1

\section{Conflict-of-interest notification}

I, the author of this article, bindingly and explicitly declare of the partial and total lack of actual or potential conflict of interest with any other third party whatsoever, which may arise as a result of the publication of this article. This statement relates to the study, data collection and interpretation, writing and preparation of the article, and the decision to submit the manuscript for publication. 